\title{
Paradoxical effects of insulin on cardiac L-type calcium current and on contraction at physiological temperature
}

\author{
V. K. Pabbathi ${ }^{1}$ M. S. Suleiman ${ }^{1}$ J. C. Hancox ${ }^{2}$ \\ ${ }^{1}$ Bristol Heart Institute, University of Bristol, Bristol, UK \\ 2 Department of Physiology and Cardiovascular Research Laboratories, School of Medical Sciences, University of Bristol, Bristol, \\ UK
}

\section{Abstract}

Aims/hypothesis. L-type calcium current $\left(\mathrm{I}_{\mathrm{Ca}, \mathrm{L}}\right)$ is a major determinant of mammalian cardiac contraction, and data from studies performed at room temperature suggest that this current is stimulated by insulin. This investigation aimed to determine whether or not insulin stimulates cardiac $\mathrm{I}_{\mathrm{Ca}, \mathrm{L}}$ at $37^{\circ} \mathrm{C}$.

Methods. Isolated guinea pig ventricular myocytes were studied at room temperature and at $37^{\circ} \mathrm{C}$. Myocytes were either field stimulated or whole-cell voltage clamped, and cell shortening was measured using video edge detection.

Results. Insulin stimulated $\mathrm{I}_{\mathrm{Ca}, \mathrm{L}}$ at ambient temperature. However, at $37^{\circ} \mathrm{C}$ the effect of insulin was to decrease rather than to increase $\mathrm{I}_{\mathrm{Ca}, \mathrm{L}}$. This action was concentration dependent and was not associated with voltage shifts in steady-state activation or inactivation properties of $\mathrm{I}_{\mathrm{Ca}, \mathrm{L}}$. At $37^{\circ} \mathrm{C}$, insulin increased the extent of myocyte contraction despite producing a significant decrease in $\mathrm{I}_{\mathrm{Ca}, \mathrm{L}}$ amplitude.

Conclusions/interpretation. The findings of this study indicate that temperature is a key experimental variable in the study of the physiological actions of insulin. Furthermore, the increase in cardiac cell contraction by insulin at physiological temperature is not due to an increase in $\mathrm{I}_{\mathrm{Ca}, \mathrm{L}}$, but is probably due to stimulation of excitation-contraction coupling downstream of $\mathrm{I}_{\mathrm{Ca}, \mathrm{L}}$.

Keywords Calcium current · Cell shortening · Contraction · Inotropic effect · Insulin · Ventricular myocytes.

\section{Introduction}

An increased risk of heart diseases, such as cardiomyopathy and heart failure, is a recognised complication of diabetes. Moreover, insulin exerts a positive inotropic effect (an increase in the strength of muscular con-

Received: 6 November 2003 / Accepted: 5 December 2003

Published online: 6 March 2004

(C) Springer-Verlag 2004

J. C. Hancox (

Department of Physiology

and Cardiovascular Research Laboratories,

School of Medical Sciences, University of Bristol,

University Walk, Bristol, BS8 1TD UK

E-mail: jules.hancox@bristol.ac.uk

Tel.: +44-117-9289028, Fax: +44-117-9298923

Abbreviations: $\mathrm{I}_{\mathrm{Ca}, \mathrm{L}}$, L-type calcium current traction) on the normal whole heart, which is independent of its actions on glucose metabolism [1, 2, 3]. Understanding the physiological mechanisms by which insulin modulates cardiac contraction is therefore important for the development of treatment strategies for heart patients with and without diabetes. Since it is widely accepted that cardiac contraction depends on $\mathrm{Ca}^{2+}$ flux into cardiac myocytes, the inotropic effect of insulin may involve a modulation of transsarcolemmal $\mathrm{Ca}^{2+}$ movement [2]. The precise mechanism underlying the effect of insulin on $\mathrm{Ca}^{2+}$ fluxes during excitation-contraction is not known, but it could involve modulation of the activity of L-type $\mathrm{Ca}^{2+}$ channels. In studies conducted at hypothermic temperatures, insulin was found to stimulate cardiac L-type $\mathrm{Ca}^{2+}$ channel current $\left(\mathrm{I}_{\mathrm{Ca}, \mathrm{L}}\right)[4,5]$. The present study was undertaken to determine the effects of insulin on $\mathrm{I}_{\mathrm{Ca}, \mathrm{L}}$ at $37^{\circ} \mathrm{C}$ and on contraction in isolated guinea pig ventricular myocytes. 


\section{Materials and methods}

Myocyte isolation and application of insulin. Male guinea pigs (400-600 g) were humanely killed using a UK Home Officeapproved 'Schedule 1' procedure. Ventricular myocytes were isolated using an enzymatic dispersal method as previously described [6], then placed in a recording chamber and superfused with Tyrode's solution containing $140 \mathrm{mmol} / \mathrm{l} \mathrm{NaCl}, 5 \mathrm{mmol} / \mathrm{l}$ HEPES, $10 \mathrm{mmol} / \mathrm{l}$ glucose, $4 \mathrm{mmol} / \mathrm{l} \mathrm{KCl}, 2.5 \mathrm{mmol} / \mathrm{l} \mathrm{CaCl}_{2}$ and $1 \mathrm{mmol} / \mathrm{l} \mathrm{MgCl}_{2}$ (pH adjusted to 7.45 using $\mathrm{NaOH}$ ). Aristar grade chemicals were used (BDH, Poole, Dorset, UK). Insulin (bovine pancreas; Sigma-Aldrich, Gillingham, Dorset, UK) was added to this solution from a $35-\mathrm{mmol} / \mathrm{l}$ stock solution made up in water, adjusted to $\mathrm{pH} 2$ with $\mathrm{HCl}$. Prior to recording, cells were pre-incubated for $10 \mathrm{~min}$ in normal Tyrode's solution alone (Control), or in insulin-containing Tyrode's solution ([Insulin], with insulin also present throughout recording). An insulin concentration of $1 \mu \mathrm{mol} / \mathrm{l}$ was used in all experiments presented in the 'Results and discussion', except when concentration-dependent modulation of $\mathrm{I}_{\mathrm{Ca}, \mathrm{L}}$ was studied (Fig. 1e), for which a range of concentrations between $100 \mathrm{nmol} / \mathrm{l}$ and $1 \mu \mathrm{mol} / \mathrm{l}$ were tested.

Voltage clamp technique. Whole-cell patch clamp experiments were performed using an Axopatch 200A amplifier (Axon Instruments, Union City, Calif., USA). The methods for preparing patch pipettes and for acquiring and processing data have already been described [7].

L-type Ca2+ current $(\mathrm{ICa}, L)$ measurement. A Cs ${ }^{+}$-based internal dialysis solution was used for selective $\mathrm{I}_{\mathrm{Ca}, \mathrm{L}}$ recording. Its composition was as follows: $113 \mathrm{mmol} / \mathrm{l} \mathrm{CsCl}$ (to block outward $\mathrm{K}^{+}$currents); $5 \mathrm{mmol} / \mathrm{l} \mathrm{K}_{2} \mathrm{ATP}$; $0.4 \mathrm{mmol} / \mathrm{l} \mathrm{MgCl}_{2}$; $2 \mathrm{mmol} / \mathrm{l} \quad \mathrm{K}_{2}$ EGTA (to block $\mathrm{Ca}^{2+}$-activated currents); $5 \mathrm{mmol} / \mathrm{l}$ glucose; $10 \mathrm{mmol} / \mathrm{l} \mathrm{HEPES}$. The solution was titrated to $\mathrm{pH} 7.2$ using $\mathrm{CsOH}$. After the whole-cell configuration had been attained, $\mathrm{K}^{+}$-free Tyrode's solution was applied to inhibit inwardly rectifying $\mathrm{K}^{+}$current. As described previously, $\mathrm{I}_{\mathrm{Ca}, \mathrm{L}}$ was elicited by a two-step voltage protocol [7]. A prepulse from $-80 \mathrm{mV}$ to $-40 \mathrm{mV}$, to activate and then inactivate the fast $\mathrm{Na}^{+}$current, was followed by a test pulse to $+10 \mathrm{mV}$ to elicit $\mathrm{I}_{\mathrm{Ca}, \mathrm{L}}$ (records in Fig. 1 show only the current during the $+10 \mathrm{mV}$ test pulse). Voltage-dependent activation and inactivation plots for $\mathrm{I}_{\mathrm{Ca}, \mathrm{L}}$ were obtained using the protocols shown schematically in Fig. 1g, reconstructing mean activation and inactivation relations as described previously [8].

Measuring unloaded cell shortening of isolated ventricular myocytes at $37^{\circ} \mathrm{C}$. For this part of the study we used a videobased edge detection system (Crescent Electronics, Sandy, Utah, USA). For experiments on undialysed cells, myocytes were field stimulated at $0.2 \mathrm{~Hz}$. Where cell shortening and ionic currents were measured concurrently, patch pipettes were filled with a 'physiological' $\mathrm{K}^{+}$-based pipette solution of $113 \mathrm{mmol} / \mathrm{l} \mathrm{KCl}, 10 \mathrm{mmol} / \mathrm{l} \mathrm{NaCl}, 5 \mathrm{mmol} / \mathrm{l} \mathrm{K}_{2} \mathrm{ATP}$, $0.4 \mathrm{mmol} / \mathrm{l} \mathrm{MgCl}_{2}, 5 \mathrm{mmol} / \mathrm{l}$ glucose and $10 \mathrm{mmol} / \mathrm{l} \mathrm{HEPES}$. The solution was titrated to $\mathrm{pH} 7.2$ with $\mathrm{KOH}$. Lidocaine $(200 \mu \mathrm{mol} / \mathrm{l})$ was present in the external solution to block any residual $\mathrm{Na}^{+}$current.

Data analysis. Data are expressed as means \pm SEM. Numbers of cells from which particular observations were obtained are given in parentheses in the 'Results and discussion' or in the figure legends. Statistical comparisons were made using the Student's $t$ test or analysis of variance where appropriate. Statistical significance was accepted as $p$ being less than 0.05 .

\section{Results and discussion}

Figures $1 \mathrm{a}$ and $\mathrm{b}$ show representative $\mathrm{I}_{\mathrm{Ca}, \mathrm{L}}$ records and mean data in the absence and presence of $1 \mu \mathrm{mol} / \mathrm{l}$ insulin at room temperature $\left(18-21^{\circ} \mathrm{C}\right)$. These data confirm previous reports $[4,5]$, showing an increase in $\mathrm{I}_{\mathrm{Ca}, \mathrm{L}}$ magnitude with insulin $(t$ test; $p<0.05)$. Figures $1 \mathrm{c}$ and $\mathrm{d}$ show corresponding data at $37^{\circ} \mathrm{C}$. Surprisingly, and in marked contrast with the room temperature data, at $37^{\circ} \mathrm{C}$ insulin decreased the magnitude of $\mathrm{I}_{\mathrm{Ca}, \mathrm{L}}(p<0.05)$. This difference in insulin action between room temperature and $37^{\circ} \mathrm{C}$ was also observed when $\mathrm{I}_{\mathrm{Ca}, \mathrm{L}}$ was normalised to cell size (membrane capacitance). The inhibitory effect of insulin at $37^{\circ} \mathrm{C}$ was concentration dependent (Fig. 1e). The significant inhibitory effect $(p<0.05)$ at a relatively low insulin concentration $(100 \mathrm{nmol} / \mathrm{l})$ suggests that this finding has physiological and pathological relevance. Halfmaximal activation voltage and slope factor parameters derived from Boltzmann fits to current-voltage plots [7] were $-11.25 \pm 2.29 \mathrm{mV}$ and $7.55 \pm 1.01 \mathrm{mV}$ respectively in controls $(n=5)$, and $-11.10 \pm 1.36 \mathrm{mV}$ $(p>0.1$ vs control) and $4.56 \pm 0.32 \mathrm{mV}(p<0.05$ vs control) respectively in $1 \mu \mathrm{mol} / \mathrm{l}$ insulin $(n=5)$. For voltage-dependent inactivation, half-maximal inactivation voltage and slope factor values were $-30.60 \pm 1.58 \mathrm{mV}$ and $7.10 \pm 1.13 \mathrm{mV}$ respectively in controls $(n=5)$, and $-27.53 \pm 2.27 \mathrm{mV}$ and $9.03 \pm 1.05 \mathrm{mV}$ (both $p>0.05 \mathrm{vs}$ control) respectively in $1 \mu \mathrm{mol} / \mathrm{l}$ insulin $(n=6)$. These mean values were used to produce the activation and inactivation plots in Fig. 1f [7], where the relations for control and insulin tests are closely overlaid. Thus, in contrast to previous data from vascular smooth muscle cells [8], the decrease in cardiac $\mathrm{I}_{\mathrm{Ca}, \mathrm{L}}$ with insulin did not correlate with shifts in voltage-dependent $\mathrm{I}_{\mathrm{Ca}, \mathrm{L}}$ kinetics.

It is well known that $\mathrm{I}_{\mathrm{Ca}, \mathrm{L}}$ provides the main source of sarcolemmal $\mathrm{Ca}^{2+}$ entry for the process of calciuminduced calcium release during cardiac excitation-contraction coupling [9]. Intriguingly, a previous study has shown no positive inotropic effect of insulin on cultured normal ventricular myocytes at $30^{\circ} \mathrm{C}$ [10]. Figure 2a shows that cell shortening of field-stimulated, undialysed myocytes at $37^{\circ} \mathrm{C}$ was greater in the presence of insulin $(1 \mu \mathrm{mol} / \mathrm{l})$. Mean control shortening was $19.14 \pm 1.55 \%$ resting cell length $(n=8)$; shortening with insulin was $27.47 \pm 0.97 \%$ resting cell length $(n=8)$. The positive inotropic effect observed under these conditions clearly indicates a direct inotropic effect of insulin on cardiac myocytes, independent of any effects of insulin on other cardiovascular tissues (e.g. the microvasculature). Further experiments were performed on patch-clamped cells to enable joint measurement of cell shortening and $\mathrm{I}_{\mathrm{Ca}, \mathrm{L}}$. Figure $2 \mathrm{~b}$ shows representative recordings under control and insulin conditions, whilst Figs. 2c and d show mean data for cell shortening and $\mathrm{I}_{\mathrm{Ca}, \mathrm{L}}$ amplitude respectively. In absolute terms, cell shortening from 
a

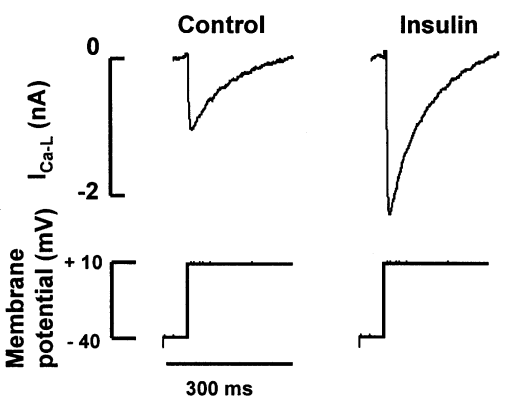

C
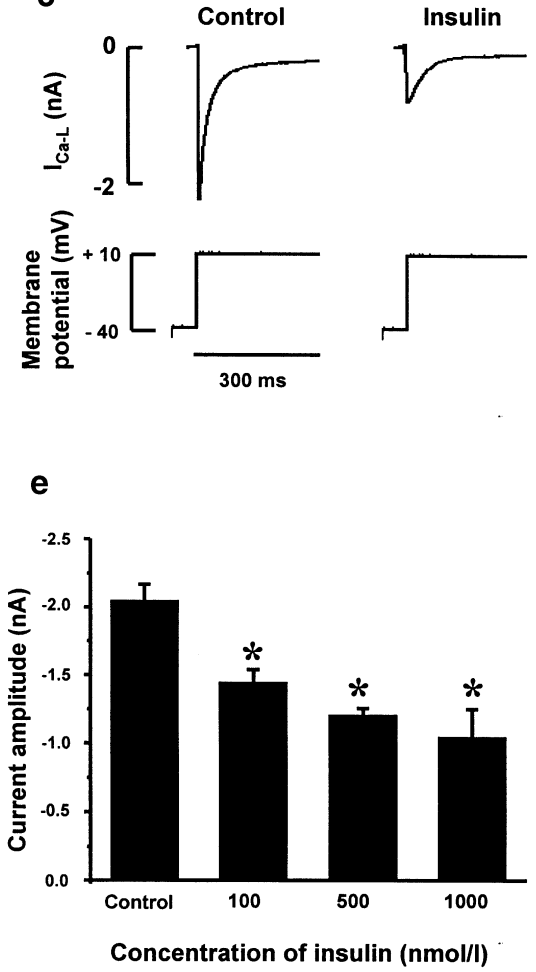

Fig. 1a-f. Effect of insulin on $\mathrm{I}_{\mathrm{Ca}, \mathrm{L}}$. Data in bar charts are means \pm SEM. ${ }^{*} p<0.05$ vs control. (a) Representative traces of peak $\mathrm{I}_{\mathrm{Ca}, \mathrm{L}}$ measured at room temperature. (b) Stimulation of $\mathrm{I}_{\mathrm{Ca}, \mathrm{L}}$ at $+10 \mathrm{mV}$ by insulin at room temperature $(n=7$ for each group). (c) Representative traces of peak $\mathrm{I}_{\mathrm{Ca}, \mathrm{L}}$ measured at $37^{\circ} \mathrm{C}$. (d) Inhibition of $\mathrm{I}_{\mathrm{Ca}, \mathrm{L}}$ at $10 \mathrm{mV}$ by insulin at $37^{\circ} \mathrm{C}$ (control, $n=22$; insulin, $n=10)$. (e) Concentration dependence of insulin effect on $\mathrm{I}_{\mathrm{Ca}, \mathrm{L}}$ at $37^{\circ} \mathrm{C}$ (control, $n=22 ; 100 \mathrm{nmol} / 1$ insulin, $n=5 ; 500 \mathrm{nmol} / 1$ insulin, $n=7 ; 1000 \mathrm{nmol} / 1$ insulin, $n=10)$. (f) Steady-state voltage-dependent activation (left) and inactivation (right) curves without $(\square)$ or with $(\square)$ insulin. Halfmaximal voltage and slope factor values for activation and for inactivation were derived from experiments with protocols shown in insets and were then used to simulate activation and inactivation variables at $2 \mathrm{mV}$ intervals b

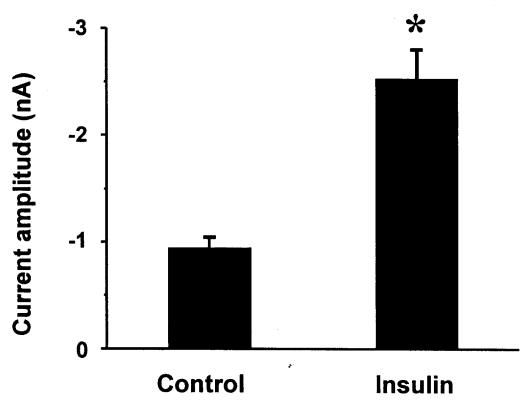

d
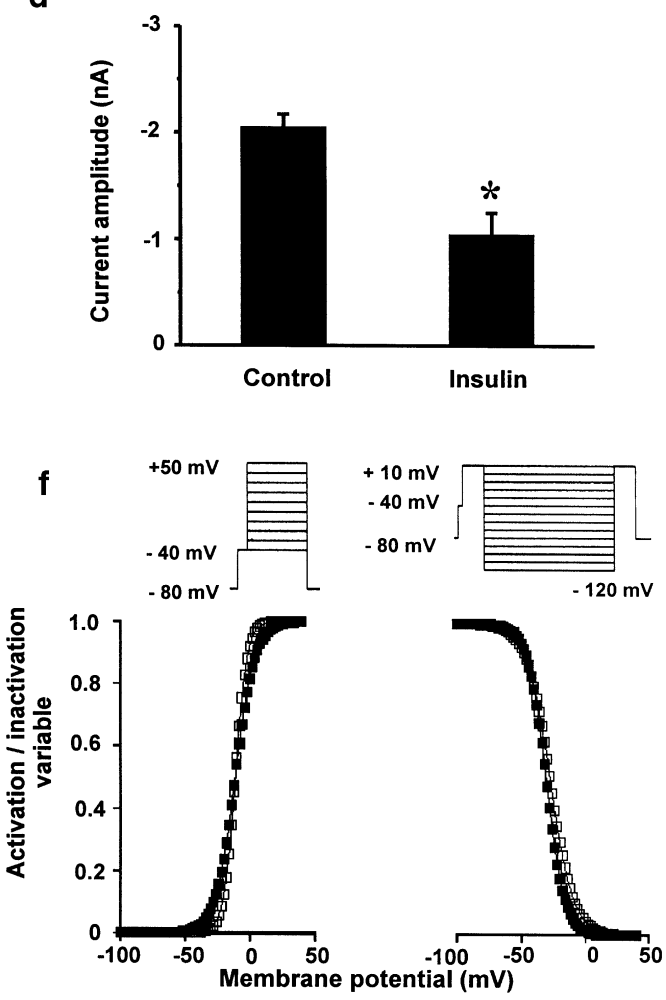

patch-clamped cells was less than that observed from field-stimulated cells, possibly as a result of equilibration of intracellular contents with the pipette dialysate in these experiments. Nevertheless, cell shortening in dialysed cells was increased by insulin, whilst $\mathrm{I}_{\mathrm{Ca}, \mathrm{L}}$ amplitude was decreased (Fig. 2d).

Three main conclusions can be drawn from this study. Firstly, cardiac effects of insulin observed at ambient temperature cannot be extrapolated to the physiological situation at $37^{\circ} \mathrm{C}$. This conclusion may also be relevant to the interpretation and design of studies of insulin action on other tissues and organs. Secondly, the signalling pathways downstream of the insulin receptor and/or the interaction between insulin and its receptor in cardiac myocytes are sufficiently temperature sensitive for the net effects of insulin receptor activation on whole-cell $\mathrm{I}_{\mathrm{Ca}, \mathrm{L}}$ to be opposite at room temperature from those at $37^{\circ} \mathrm{C}$. The stimulatory effect of insulin on $\mathrm{I}_{\mathrm{Ca}, \mathrm{L}}$ at room temperature reported 
a

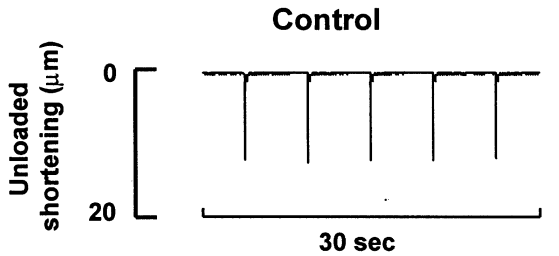

Insulin

b

Control
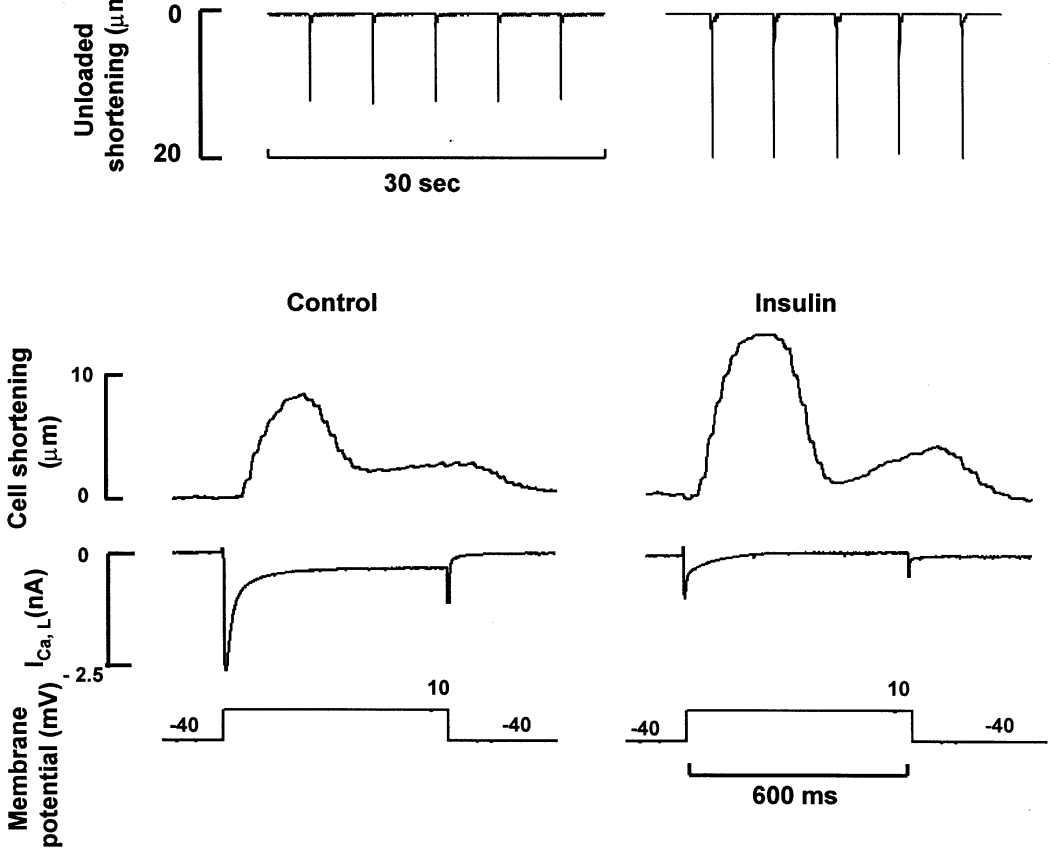

C

d

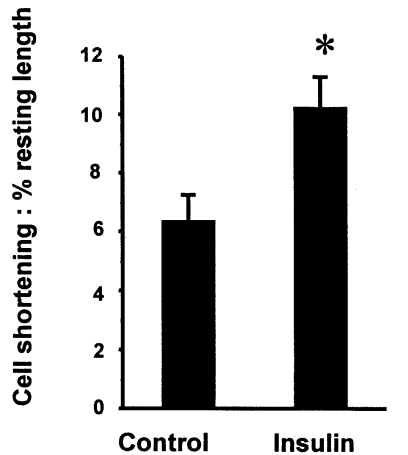

Fig. 2a-d. Effect of insulin on heart cell shortening (contraction) at $37^{\circ} \mathrm{C}$. Data in bar charts are means \pm SEM. ${ }^{*} p<0.05$ vs control. (a) The effect of $1 \mu \mathrm{mol} / \mathrm{l}$ insulin on shortening (downward deflections) of externally stimulated myocytes. (b) Combined measurements of cell shortening (upper traces) and ionic current (middle traces) under voltage clamp (lower traces) from a control myocyte and a myocyte incubated in insulin. (c) Data regarding stimulation of cell shortening in dialysed cells by insulin ( $n=6$ for each group). (d) Data for $\mathrm{I}_{\mathrm{Ca}, \mathrm{L}}$ amplitude at $+10 \mathrm{mV}$ in control myocytes and in myocytes incubated in insulin (same cells as in $\mathbf{c} ; n=6$ for each group)

previously $[4,5]$ was attributed to a stimulation of cyclic adenosine monophosphate-dependent protein kinase. Clearly, the pathways responsible for the inhibitory effect of insulin on $\mathrm{I}_{\mathrm{Ca}, \mathrm{L}}$ at $37^{\circ} \mathrm{C}$ must now be elucidated. Thirdly, the positive inotropic action of insulin, reported in the intact normal heart, is the result of direct action of insulin on myocytes, which cannot be explained by a stimulation of $\mathrm{Ca}^{2+}$ entry via $\mathrm{I}_{\mathrm{Ca}, \mathrm{L}}$.

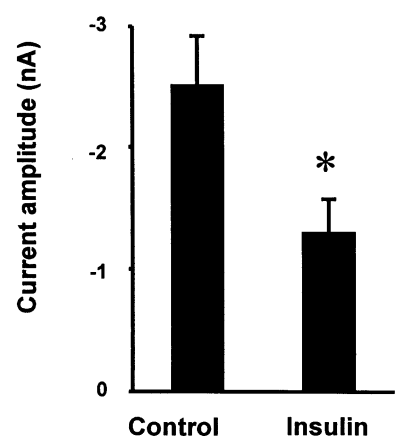

Rather, the overall 'gain' of the excitation-contraction coupling process was increased. Further investigations are warranted in order to determine which steps of the process are modulated by insulin to account for the observed inotropic effect at physiological temperature. These will probably need to combine the techniques used in the present study with measurements of intracellular $\mathrm{Ca}^{2+}$ to determine: (i) the effects of insulin on intracellular $\mathrm{Ca}^{2+}$ handling (particularly by the intracellular stores in the sarcoplasmic reticulum) and on myofilament $\mathrm{Ca}^{2+}$ sensitivity; and (ii) whether and how the $\mathrm{I}_{\mathrm{Ca}, \mathrm{L}}$ and contraction of diabetic and normal hearts differ in their response to insulin. Collectively, the present data and the proposed future work will provide information valuable to the rational development of strategies to protect and treat the myocardium in diabetic and non-diabetic patients.

Acknowledgements. The authors thank Lesley Arberry for assistance with myocyte isolation, Mark Ginty for technical help, and the National Heart Research Fund for financial support. 


\section{References}

1. Lucchesi BR, Medina M, Kniffen FJ (1972) The positive inotropic action of insulin in the canine heart. Eur J Pharmacol 18:107-115

2. Schmidt HD, Koch M (2002) Influence of perfusate calcium concentration on the inotropic insulin effect in isolated guinea pig and rat hearts. Basic Res Cardiol 97:305-311

3. Doenst T, Richwine RT, Bray MS, Goodwin GW, Frazier OH, Taegtmeyer H (1999) Insulin improves functional and metabolic recovery of reperfused working rat heart. Ann Thorac Surg 67:1682-1688

4. Aulbach F, Simm A, Maier S et al. (1999) Insulin stimulates the L-type $\mathrm{Ca}^{2+}$ current in rat cardiac myocytes. Cardiovasc Res 42:113-120

5. Maier S, Aulbach F, Simm A et al. (1999) Stimulation of L-type $\mathrm{Ca}^{2+}$ current in human atrial myocytes by insulin. Cardiovasc Res 44:390-397
6. Levi AJ, Issberner J (1996) Effect on the fura-2 transient of rapidly blocking the $\mathrm{Ca}^{2+}$ channel in electrically stimulated rabbit heart cells. J Physiol 493:19-37

7. Witchel HJ, Pabbathi VK, Hofmann G, Paul AA, Hancox JC (2002) Inhibitory actions of the selective serotonin re-uptake inhibitor citalopram on HERG and ventricular L-type calcium currents. FEBS Lett 512:59-66

8. Standley PR, Zhang F, Ram JL, Zemel MB, Sowers JR (1991) Insulin attenuates vasopressin-induced calcium transients and a voltage-dependent calcium response in rat vascular smooth muscle cells. J Clin Invest 88: $1230-1236$

9. Bers DM (2001) Excitation-contraction coupling and cardiac contractile force. Kluwer, Dordrecht

10. Ren J, Walsh MF, Hamaty M, Sowers JR, Brown RA (1999) Augmentation of the inotropic response to insulin in diabetic rat hearts. Life Sci 65:365-380 